\title{
Influence of dissolved oxygen concentration and aeration time on nitrite accumulation in partial nitrification process
}

\author{
${ }^{2}$ X. Guo; ${ }^{3}$ J. H. Kim; ${ }^{1}$ S. K. Behera; ${ }^{1 *}$ H. S. Park \\ ${ }^{1}$ Department of Civil and Environmental Engineering, University of Ulsan, Ulsan 680-749, Republic of Korea \\ ${ }^{2}$ School of Environment, Beijing Normal University, Beijing, China 100875 \\ ${ }^{3}$ Ulsan Eco Centre, Korea Industrial Complex Corporation, Republic of Korea
}

Received 8 June 2008; $\quad$ revised 15 July 2008; accepted 29 July 2008; available online 1 September 2008

\begin{abstract}
This study investigated the influence of dissolved oxygen concentration and aeration time on nitrification and nitrite accumulation in an attempt to optimize the recently developed biological-partial-nitritation process for the treatment of strong nitrogen wastewaters. Investigation of dissolved oxygen concentration on ammonium and nitrite

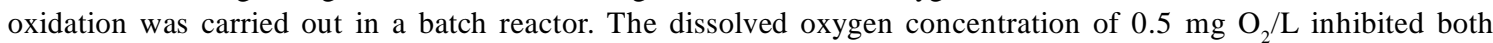
ammonium as well as nitrite oxidation, while increase of dissolved oxygen concentration to $\sim 1 \mathrm{mg} \mathrm{O} / 2$ increased the ammonium oxidation rate and was comparable to that at higher dissolved oxygen concentrations. Experiments were carried out in a sequencing batch reactor for more than 100 days to investigate the influence of aeration time on nitrite accumulation. The dissolved oxygen concentration was controlled at $\sim 1.0 \mathrm{mg} \mathrm{O}_{2} / \mathrm{L}$ (in the range of $0.8-1.5 \mathrm{mg} / \mathrm{L}$ ) during the aeration stage, and volatile suspended solid was maintained at $2.0 \mathrm{~g} / \mathrm{L}$ while temperature and $\mathrm{pH}$ were $30 \pm 1^{\circ} \mathrm{C}$ and $8.3 \pm 0.1$, respectively. In a typical cycle, complete nitrification occurred at aeration time longer than $6 \mathrm{~h}$. When the aeration time was reduced to $4 \mathrm{~h} ., \sim 80 \%$ of partial nitritation was achieved. With a further reduction in aeration time to 3 h., nearly 1:1 nitrite/ammonium ratio was yielded. This result revealed that for the reactor design, aeration time determined by feasibility experiments must be considered based on the nitrogen strength in wastewater and biomass concentration in the reactor with dissolved oxygen concentration of $\sim 1.0 \mathrm{mg} \mathrm{O}_{2} / \mathrm{L}$ for satisfactory partial nitrification with subsequent processes such as anaerobic ammonium oxidation.
\end{abstract}

Key words: Sequencing batch reactor, ammonium oxidation, nitrite oxidation, volatile suspended solid

\section{INTRODUCTION}

Treatment of wastewater with high ammonium strength has become a matter of serious concern in the recent days (Verstraete and Philips, 1998; Khin and Annachhatre, 2004; Ahn, 2006). A representative example is the highly concentrated ammonia removal from the municipal landfill leachates, food processing wastewater, liquid wastes from animal production plants, condensates from fertilizer plants, and the supernatant from anaerobic sludge digesters, where the ammonia content can reach 600-1000 $\mathrm{mg} \mathrm{NH}_{4}{ }^{+} \mathrm{N} / \mathrm{L}$ Fux et al., 2006; Galí et al., 2006). The physico-chemical processes such as air and steam stripping are sometimes used for the nitrogen control from these types of wastewater (EPA, 1993). However, from environmental and economical view point, biological nitrogen removal (BNR) could be more interesting for treating strong nitrogen wastewater (Teichgraber and

$\triangle$ *Corresponding Author Email: parkhs@ulsan.ac.kr

Tel: +82 52259 1050; Fax: +82 522210152
Stein, 1994). BNR has been widely adopted in preference to the physicochemical processes because of its higher effectiveness and relative cheapness, especially in the field of municipal wastewater treatment (EPA, 1993). Traditional BNR generally involves aerobic nitrification with the terminal conversion of $\mathrm{NH}_{4}^{+}$to $\mathrm{NO}_{3}{ }_{3}^{-}$and anoxic denitrification with the conversion of $\mathrm{NO}_{3}^{-}$to gaseous nitrogen (Tchobanoglous et al., 2002). The drawback of conventional nitrification/denitrification is that it consumes a large amount of oxygen and always requires addition of electron donors such as methanol, acetate, and ethanol, which makes full-scale denitrification quite expensive for the treatment of nitrogen-laden wastewaters (EPA, 1975; McCarty et al., 1969). Particularly for the high-strength ammonium wastewater as noted above, high amount of oxygen consumption and large quantity of external carbon requirement make the traditional biological nitrification/ denitrification process more expensive. Recently, new 
processes such as SHARON and ANAMMOX have been developed to treat wastewater with high nitrogen content and low quantity of biodegradable organic materials (Hellinga et al., 1997; Mulder et al., 1995; Dijkman and Strous, 1999). Aiming at lowering the oxygen demand and reducing or avoiding organic substrate requirement, the newly developed processes are essentially based on partial nitrification of ammonium to nitrite (Galí et al., 2006; Fux et al., 2002; Mosquera-Corral, et al., 2005; Ciudad et al., 2005). To achieve the shortcut of nitrate formation, the potential strategies for the stable nitrite accumulation include the control of operating variables such as $\mathrm{pH}$, hydraulic retention time (HRT), solid retention time (SRT), dissolved oxygen (DO) concentration, temperature (Ruiz et al., 2003; Kim et al., 2006; Tseng et al.,1998; Bougard et al., 2006), and the screening of different reactor configurations such as SHARON reactor and sequencing batch reactor (SBR) (Fux et al., 2006; Galí et al., 2006; Antileo et al., 2006; Chuang et al., 2007). The control of an appropriate DO concentration is one of the most practical strategies to achieve nitrification via nitrite. In the last two decades, the influence of DO concentration on the biological nitrification kinetics was extensively investigated using both pure and mixed cultures (Stenstrom and Poduska, 1980; Beccari et al., 1992). However, the effect of DO concentration on nitrite accumulation did not attract much attention until the recent emergence of partial nitrification processes. Currently, a number of publications have discussed partial nitrification under various DO concentrations (Ciudad et al., 2005; Ruiz et al., 2006; Bae et al., 2002; Wang and Yang, 2004). The maintenance of DO concentration includes operation and installation cost of air supply equipments and the aeration time influences the capital cost of reactor size and operational cost to a large extent. Although the aeration time has a significant impact while designing the reactors based on the wastewater characteristics and MLSS concentration, that the influence of aeration time on the nitrite accumulation is poorly documented.

In this paper, first of all the dependence of nitrite accumulation on DO has been studied using batch method. Then the influence of aeration time on partial nitrification has been explored by employing the SBR configuration for more than 100 days. This study will help to gain further insight on newly developed biological nitritation processes applied to strong nitrogen wastewater treatment. This study was carried out in the laboratory for a period of 18 months from March 2005 to August 2006.

\section{MATERIALS AND METHODS}

\section{Cultivation of nitrifiers}

The seed sludge was obtained from an activated sludge tank of Yongyeon municipal wastewater treatment facility in Ulsan City. The cells were grown and cultured in an $8 \mathrm{~L}$ membrane biological reactor (MBR) (made up of plexi-glass) for one year before the batch experiments. The inorganic medium for the cells growth contained (mg/L): $\mathrm{CaCl}_{2} 7, \mathrm{FeCl}_{3} 1, \mathrm{KCl} 7$, $\mathrm{KH}_{2} \mathrm{PO}_{4} 11, \mathrm{MgSO}_{4}$ 5, $\mathrm{Na}_{2} \mathrm{HPO}_{4} 29, \mathrm{NaHCO}_{3} 6000$, $\mathrm{NH}_{4} \mathrm{Cl}$ as $\mathrm{N} 500$. The substrate was fed with a peristaltic pump at a flow rate of $24 \mathrm{~L} / \mathrm{d}$, corresponding to a nitrogen load rate of $1.5 \mathrm{~kg} \mathrm{NH}_{4}{ }^{+}-\mathrm{N} / \mathrm{m}^{3} / \mathrm{d}$. The temperature and the DO in the MBR were kept at $20 \pm 2{ }^{\circ} \mathrm{C}$ and $3 \mathrm{mg} / \mathrm{L}$ respectively. The $\mathrm{pH}$ was regulated constantly at $8.3 \pm 0.1$ by titration with $6 \mathrm{~g} / \mathrm{L} \mathrm{NaHCO}_{3}$ solution. During the steady state of the acclimation, the influent ammonium was almost entirely oxidized to nitrate and the nitrite concentration was approximately $15 \mathrm{mg} \mathrm{N} / \mathrm{L}$. The volatile suspended solid (VSS) in MBR was around $3.20 \mathrm{~g} \mathrm{VSS/L}$ when the nitrifiers were harvested by centrifugation. The harvested cells were washed with fresh water before use.

\section{Batch experiment at various DO concentrations}

All batch experiments were conducted in a reactor containing 2 L synthetic wastewater, which had the same substrate concentrations as that of the nitrifierscultivation experiment except the initial ammonium concentration. Air was supplied from the bottom of the batch reactor through an air sparger. The DO concentration was measured by a DO analyzer and was designed at a certain value in the range of 0.5 to 6 $\mathrm{mg} \mathrm{O}_{2} / \mathrm{L}$ by controlling the air flow rate with the help of a flow rate meter and solenoid valve. The desired temperature of $30^{\circ} \mathrm{C}$ was kept constant by placing the batch reactor in a water bath, through which the water with the desired temperature was continuously pumped from a chiller. With an initial ammonium concentration of $125 \mathrm{mg} \mathrm{N} / \mathrm{L}$, the concentration of VSS was designed at $2.20 \mathrm{~g} \mathrm{VSS} / \mathrm{L}$, while in another set of tests with ammonium concentration of $275 \mathrm{mg} \mathrm{N} / \mathrm{L}$, the VSS concentration was designed as $1.20 \mathrm{~g} \mathrm{VSS} / \mathrm{L}$. The desired VSS concentrations were achieved by diluting the MLVSS collected from the MBR configuration. In all the batch tests, $\mathrm{pH}$ was again regulated at $8.3 \pm 0.1$. 
Int. J. Environ. Sci. Tech., 5 (4), 527-534, Autumn 2008

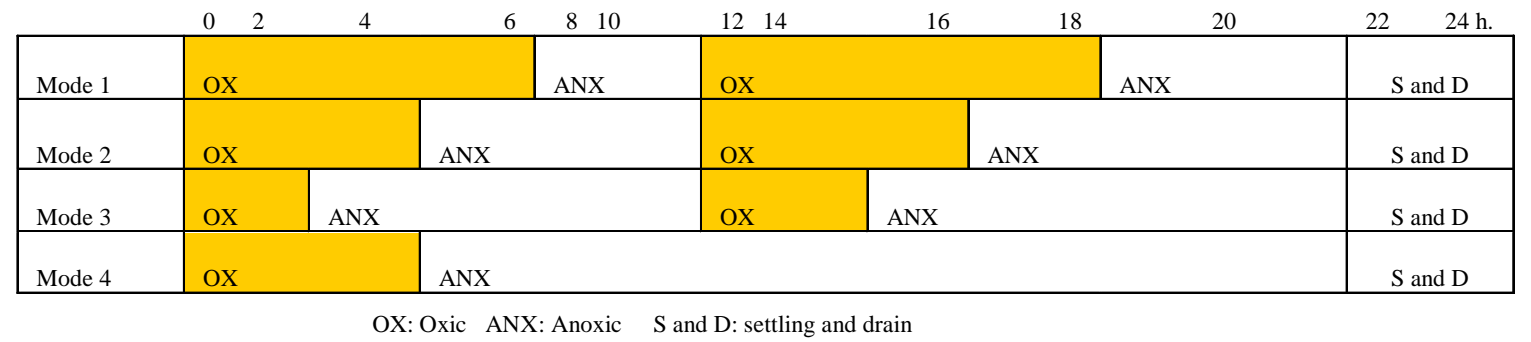

Fig. 1: The aeration pattern for four operating modes

Sequencing batch reactor test with different aeration time

A SBR with $4 \mathrm{~L}$ working volume was equipped with an air sparger, magnetic stirrer, and online measurement of DO concentration and $\mathrm{pH}$. The reactor was inoculated with the acclimated nitrifiers described above. Synthetic wastewater contained $500 \mathrm{mg} / \mathrm{L}$ of ammonium nitrogen and the same background-ion composition as noted in above section. The aeration time of four operation modes were shown in Fig. 1.

The $24 \mathrm{~h}$. cycle of SBR with internal oxic/anoxic phases was operated for more than 100 days. The settling and drain time was $2 \mathrm{~h}$. with $40 \%$ of exchange volume per cycle. Modes 1, 2 and 3 were operated with 2 internal oxic/anoxic phases; each phase duration was 11 h., with aeration times 6,3 and 2 h., and corresponding anoxic times 5, 8, and $9 \mathrm{~h}$. , respectively. The mode 4 has only one oxic/anoxic phase with 3 hours of aeration time. The temperature and solution $\mathrm{pH}$ were kept at $30 \pm 1^{\circ} \mathrm{C}$ and $8.3 \pm 0.1$, respectively. The DO concentration was controlled at $\sim 1.0 \mathrm{mg} \mathrm{O}_{2} / \mathrm{L}$ (in the range of $0.8-1.5 \mathrm{mg} / \mathrm{L}$ ) during the aeration stage, and the VSS was maintained at $2.0 \mathrm{~g} / \mathrm{L}$.

\section{Analytical methods}

$\mathrm{NH}_{4}^{+}-\mathrm{N}$ was measured by spectrophotometric method in $425 \mathrm{~nm}$. (DR 2000, Hach, CO, USA). Nitrite and nitrate was measured by ion chromatograph (DX80; Dionex, CA, USA). Alkalinity and VSS were determined by standard methods (APHA, 1998). $\mathrm{pH}$ and DO concentration were measured by $\mathrm{pH}$ meter (420A, Orion 3-star series; Thermo scientific, MA, USA) and DO meter (815PDC, Istek, Seoul, Korea) respectively.

\section{RESULTS AND DISCUSSION}

Nitrification and nitrite accumulation at various DO concentrations

Fig. 2 presents the ammonium oxidation at different DO concentrations. The relationship of ammonium consumption with time was linearly fitted $\left(\mathrm{R}^{2}>0.99\right.$ in all cases) indicating that ammonia oxidation followed the zero-order reaction kinetics. At the initial ammonium concentration of $\sim 125 \mathrm{mg} \mathrm{N} / \mathrm{L}$, complete ammonium oxidation approached within 100 minutes for DO concentration greater than $0.5 \mathrm{mg} \mathrm{O}_{2} / \mathrm{L}$. However at the DO concentration of $0.5 \mathrm{mg} \mathrm{O}_{2} / \mathrm{L}$, only $55 \%$ of substrate conversion took place within the same time. The specific ammonium oxidation rates, as calculated from the corresponding slope of the linear regressions normalized to the VSS, were obtained as 0.74-0.88 g $\mathrm{N}$ g/VSS/d when the DO concentrations were greater than $0.5 \mathrm{mg} \mathrm{O}_{2} / \mathrm{L}$ (Table 1 ).

However at the DO of $0.5 \mathrm{mg} \mathrm{O} / \mathrm{L}$, the specific ammonium oxidation rate markedly decreased to $0.49 \mathrm{~g}$ N/g VSS/d.

Fig. 3 shows the nitrite accumulation at the fourth DO concentrations before the complete consumption of ammonium. At the DO concentration of $0.5 \mathrm{mg} / \mathrm{L}$, maximum nitrite concentration was about $15 \mathrm{mg} / \mathrm{L}$.

Table 1: The specific rate of nitrogen species fluctuation

\begin{tabular}{llll}
\hline $\begin{array}{l}\text { DO concentration } \\
\mathrm{mg} \mathrm{O}_{2} / \mathrm{L}\end{array}$ & $\begin{array}{l}\text { Specific ammonium oxidation rate } \\
\mathrm{g}_{\mathrm{N}} / \mathrm{g}_{\mathrm{VsS}} / \mathrm{d}\end{array}$ & $\begin{array}{l}\text { Specific nitrite oxidation rate } \\
\mathrm{g}_{\mathrm{N}} / \mathrm{g}_{\mathrm{VSs}} / \mathrm{d}\end{array}$ & $\begin{array}{l}\text { Specific nitrite accumulation rate } \\
\mathrm{g}_{\mathrm{N}} / \mathrm{g}_{\mathrm{Vs}} / \mathrm{d}\end{array}$ \\
\hline $0.5 \pm 0.2$ & $0.492 \pm 0.016$ & $0.422 \pm 0.018$ & $0.091 \pm 0.004$ \\
$2.0 \pm 0.2$ & $0.789 \pm 0.030$ & $0.615 \pm 0.023$ & $0.174 \pm 0.011$ \\
$3.5 \pm 0.2$ & $0.878 \pm 0.017$ & $0.688 \pm 0.015$ & $0.190 \pm 0.005$ \\
$6.0 \pm 0.2$ & $0.738 \pm 0.011$ & $0.592 \pm 0.009$ & $0.148 \pm 0.004$ \\
\hline
\end{tabular}




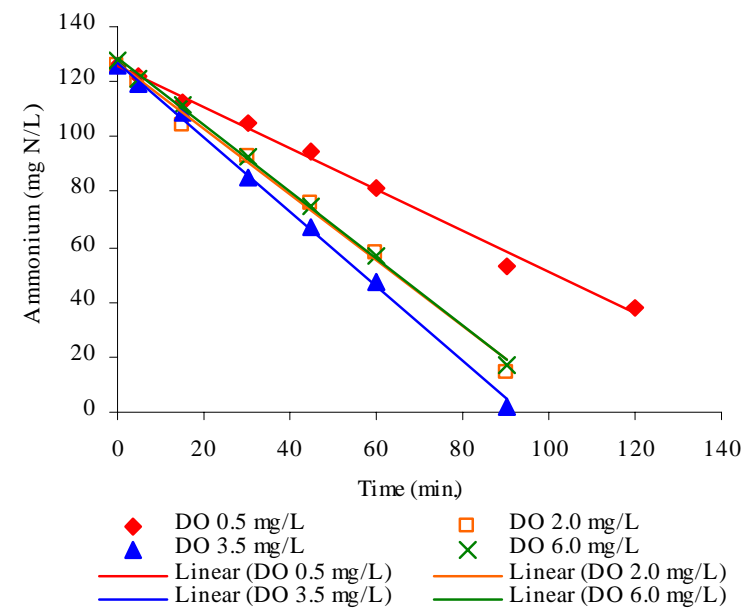

Fig. 2: Ammonium oxidation at different DO concentrations

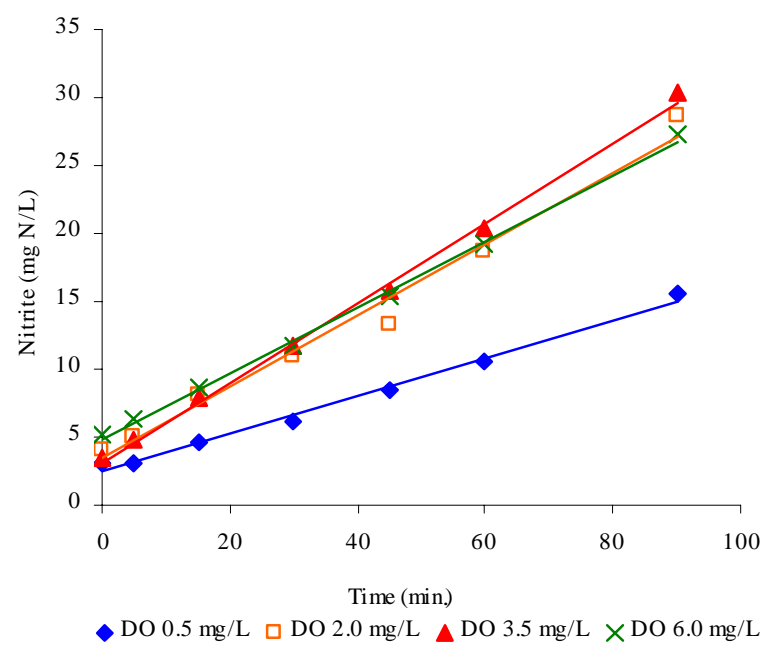

Fig. 3: Nitrite accumulation at different DO concentrations

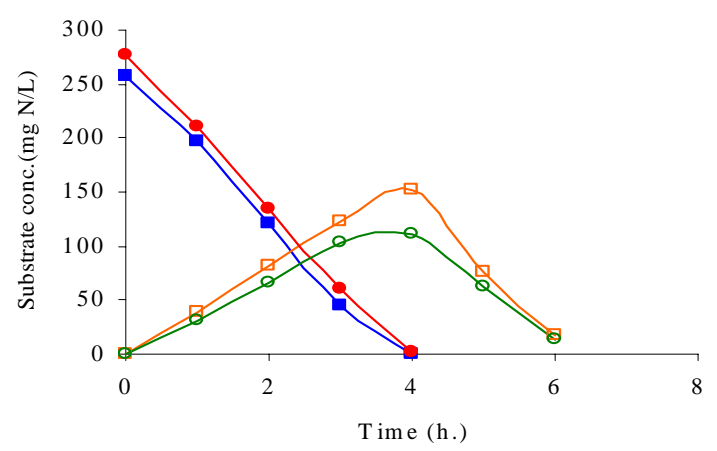

$\longrightarrow$ DO 0.8-1.5 mg/L, Ammonium $\square$ DO 0.8-1.5 mg/L, Nitrite $\longrightarrow$ DO 2.3-3.0 mg/L, Ammonium —- DO 2.3-3.0 mg/L, Nitrite

Fig. 4: Comparison of ammonium oxidation and nitrite accumulation at the DO concentrations of $0.8-1.5$ and 2.3-3.0 $\mathrm{mg} \mathrm{O}_{2} / \mathrm{L}$
However at higher DO concentrations, the nitrite concentration increased up to $28-31 \mathrm{mg} / \mathrm{L}$. The specific nitrite accumulation rate and the specific nitrite oxidation rate (derived from the specific rate of nitrate production) are exemplified in Table 1 . The specific nitrite accumulation rate at $\mathrm{DO}$ concentrations 2.0 and $3.5 \mathrm{mg} / \mathrm{L}$ was double in comparison to DO concentration at $0.5 \mathrm{mg} / \mathrm{L}$. However with a further increase of DO concentration to $6 \mathrm{mg} / \mathrm{L}$, the nitrite build-up relatively leveled off. Resembling the trend of ammonium oxidation, the specific nitrite oxidation rate was limited at DO concentration of $0.5 \mathrm{mg} / \mathrm{L}$, while for DO concentrations in the range of 2.0 to $6.0 \mathrm{mg} / \mathrm{L}$ it exhibited considerably higher values.

Considering the DO concentration of $\sim 1.0 \mathrm{mg} \mathrm{O}_{2} / \mathrm{L}$ used for the partial nitritation in the previous literatures (Ciudad et al., 2005; Galí et al., 2006; Fux et al., 2006), the nitrification kinetics and the consequent nitrite accumulation were specifically compared between the two DO concentrations of 0.8-1.5 (average 1.0) and 2.33.0 (average 2.5) $\mathrm{mg} \mathrm{O}_{2} / \mathrm{L}$. The VSS and initial ammonium concentrations were approximately set as $1200 \mathrm{~g} \mathrm{VSS} / \mathrm{L}$ and $275 \mathrm{mg}$ N/L, respectively. As illustrated in Fig. 4, at the two DO concentrations, the ammonium consumption completed after 4 h.of reaction, and at the end of the ammonium oxidation, the nitrite accumulation reached the highest point. With the further increase in time, the nitrite concentration became less due to the subsequent nitrite oxidation, which led to complete formation of nitrate within $6 \mathrm{~h}$. The slopes of ammonium oxidation curves at the two DOs were eventually identical, exhibiting an insignificant effect of DO concentration on the kinetics of ammonium oxidation at the minimum DO concentration of $1 \mathrm{mg} \mathrm{O}_{2} / \mathrm{L}$. The extent of nitrite accumulation at $0.8-1.5 \mathrm{mg} \mathrm{O} / \mathrm{L}$ was considerably higher than that at 2.3-3.0 $\mathrm{mg} \mathrm{O}_{2} / \mathrm{L}$.

Both ammonium and nitrite oxidation kinetics were negatively affected by low DO concentration of $0.5 \mathrm{mg}$ $\mathrm{O}_{2} / \mathrm{L}$ in this study. This result is in good agreement with the observations made in the previous literatures (Bae et al., 2002; Wang and Yang, 2004). Hanaki et al. (1990) reported that nitrite oxidation was strongly inhibited at DO concentration of $0.5 \mathrm{mg} / \mathrm{L}$, while the low DO levels had no effect on ammonia oxidation in the suspended-growth reactor because the growth yield of ammonia oxidizers at low DO concentration doubled and compensated the reduced specific substrate utilization rate. Considering the negligible 
Int. J. Environ. Sci. Tech., 5 (4), 527-534, Autumn 2008

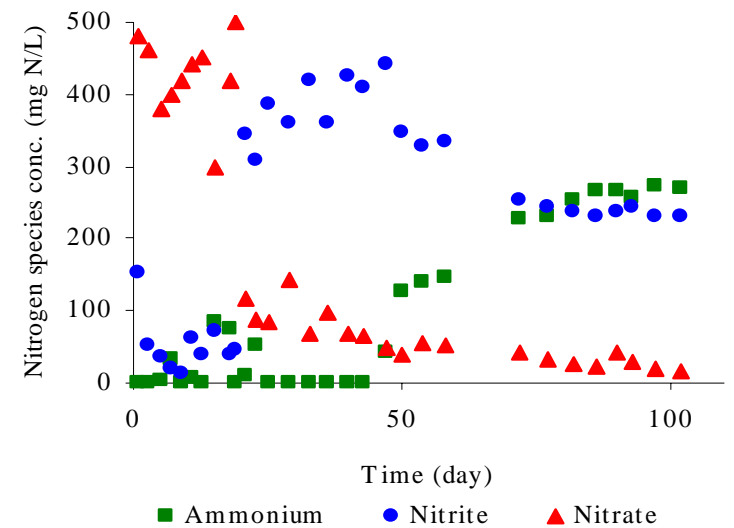

Fig. 5: Nitrogen species fluctuation from the SBR effluent with four operation modes (Mode 1 to 4 )

cell growth in the batch test of the current study, the reduced rate of nitrification kinetics at DO of $0.5 \mathrm{mg}$ $\mathrm{O}_{2} / \mathrm{L}$ is still consistent with the reports of Hanaki et al. (1990).

At a similar pH to this study, Bae et al. (2002) reported that the nitrite accumulation is considerably lower at DO concentration of $0.5 \mathrm{mg} \mathrm{O}_{2} / \mathrm{L}$ than at $\mathrm{DO}$ concentration of 1.5 and $2.5 \mathrm{mg} \mathrm{O}_{2} / \mathrm{L}$. They found that the inhibition of nitrite oxidation caused by free ammonia was the main reason for nitrite accumulation. In the present study, however, due to a strong resistance to substrate inhibition after the acclimation, the nitrite accumulation was highly dependent on the ratio of ammonia oxidation rate to nitrite oxidation rate $\left(K_{\mathrm{a}} / K_{\mathrm{n}}\right)$ and $\left(K_{\mathrm{a}} / K_{\mathrm{n}}\right)>1$ was the only reason for the nitrite accumulation. The rate of ammonium oxidation at DO concentration of $0.8-1.5 \mathrm{mg} \mathrm{O}_{2} / \mathrm{L}$ showed a comparable value with that at higher oxygen concentrations. In addition, the extent of nitrite accumulation was facilitated at $0.8-1.5 \mathrm{mg} \mathrm{O}_{2} / \mathrm{L}$. The results from the batch test were consistent with the observations made in the continuous stirred tank reactor (Ciudad et al., 2005; Ruiz et al., 2006).

Effect of aeration time on nitrification and nitrite accumulation

The nitrification study in SBR configuration was operated for 102 days. The duration of the modes 1 to 4 was 10, 10, 23, and 59 days, respectively. The total aeration time corresponding to each cycle was 12, 6, 4 and 3 h., respectively. Fig. 5 presents the concentration fluctuations of out-flow nitrogen species with four aeration patterns. For the operation modes 1, 2 and 3,

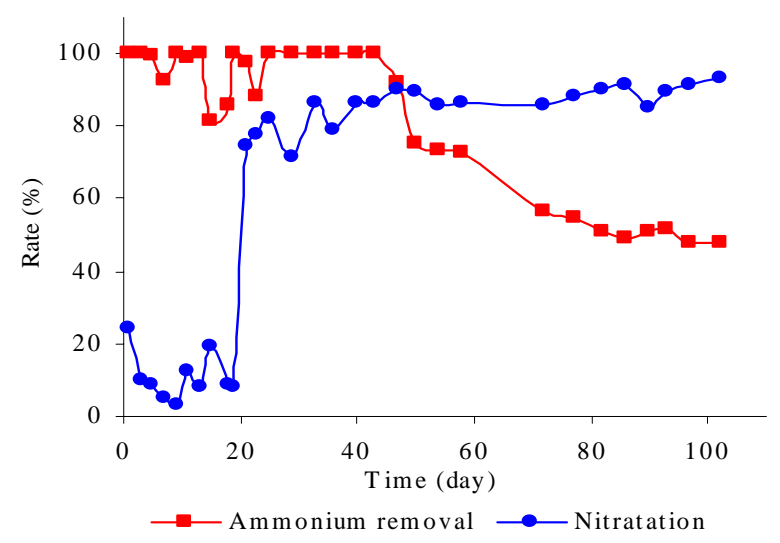

Fig. 6: Ammonium transformation percentage and nitritation rate with four operation modes (Mode 1 to 4 )

the effluent ammonium concentration was essentially negligible, indicating almost total ammonium conversion (as shown in Fig. 6.). When the operation mode shifted from 3 to 4, the percentage of ammonium transformation gradually decreased, and finally remained constant at about $50 \%$ of ammonium removal rate. Concerning the nitrification in the modes 1 and 2, it was observed that around $90 \%$ of the oxidized product was dominated with nitrate. It was interesting to note that when the aeration time was reduced to $4 \mathrm{~h}$. (mode 3 ), the nitrite accumulation was considerably facilitated, resulting in a 300-450 mg N/L of nitrite accumulation in the effluent over the 23 days of operation. As shown in Fig. 6, the ratio of nitrite formation to the sum of nitrite and nitrate production, increased drastically from $10 \%$ in mode 1 and 2 to $80 \%$ in mode 3 . With a further reduction in aeration time to 3 h. (mode 4) the nitritation rate continually increased to more than $90 \%$.

Fig. 7 presents the concentration variation of nitrogen species in a typical cycle of each operation mode. For the mode 1, complete removal of ammonium occurred even in the first $6 \mathrm{~h}$. of aeration phase. A little amount of nitrite accumulation was observed in the first phase, but completely transformed to the nitrate during the second aeration phase. Similar to the mode 1, transformation of ammonium to nitrate continually proceeded in the two successive aeration phases, resulting in a minor nitrite accumulation after $6 \mathrm{~h}$. of total aeration. Based on the results of the mode 1 and 2 , it was summarized that the nitrite accumulation was unfavorable when the aeration time was beyond $6 \mathrm{~h}$. In the typical cycle of mode 3 , the ammonium was 
progressively and most largely converted to nitrite during the two aeration phases. The nitrite accumulation became predominant at mode 4 , and the nitrate production was negligible in the whole cycle. Among the four different modes, the concentration of different species of nitrogen compounds in the anoxic phase was not significantly changed, showing a stable state when the aeration was stopped.

From the observations it was apparent that with DO concentration of $\sim 1 \mathrm{mg} \mathrm{O}_{2} / \mathrm{L}$, aeration time played a significant role to influence the nitrification performance and the proportions of nitrogen species. Under experimental conditions, complete nitrification occurred when the aeration time was longer than a certain value (6 h. in the current case); a partial nitritation was obtained when the aeration time was controlled at an appropriate time (i.e. $4 \mathrm{~h}$.). With a further decrease in aeration time to $3 \mathrm{~h}$., nearly $1: 1$ nitrite/ammonium ratio was obtained, which is suitable for the Anammox process, although the overall ammonia oxidation was reduced by two times. Therefore based on the study, it is demonstrated that appropriate aeration time for partial nitrification must be decided by feasibility study in the design stage based on the wastewater characteristics, biomass concentration and DO concentration of $\sim 1 \mathrm{mg} \mathrm{O}_{2} / \mathrm{L}$. In the recent times, this is an innovative technology with benefits, first, lower oxygen (approx. $25 \%$ ) and about $40 \%$ lower

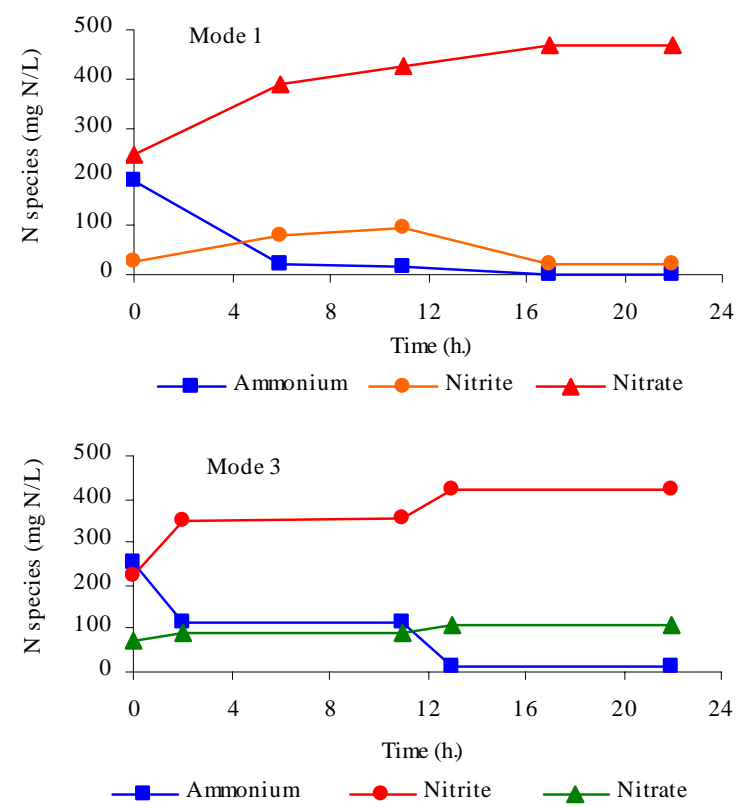

electron donors; second, denitrification rates with nitrite are usually 1.5-2 times faster than with nitrate (Abeling et al., 1992). Different approaches were used in order to restrict the nitrification process to nitrite (Mosquera-Corral et al., 2005; Bougard et al., 2006). Apparently, the control of a limited DO concentration gives a more practical way relative to the optimization of $\mathrm{pH}$ and substrate loading rate to achieve partial nitrification (Ruiz et al., 2006; Chuang et al., 2007). As an optimized aeration strategy, the selection of a proper aeration time, therefore, provided a simple approach in conjunction with the control of limited DO for the stable nitritation in the SBR configuration.

In this experiment, it is primarily focused on the effect of aeration time on partial nitrification using SBR configuration as nitrogen species which were stable during the anoxic phase as observed above. In real practice, the reduction of an anoxic-phase time can be decided considering $\mathrm{C} / \mathrm{N}$ ratios at the end of aeration time and consequently shorten the duration of a typical cycle to achieve a reasonable nitrogen removal rate. Moreover, if the denitrification process is designed to perform in a subsequent bio-reactor, the partial nitrification can even be conducted with no anoxicphase (Galí et al., 2006). Owing to the same observation of unchanged state of anoxic phase, partial nitrification appeared dependent on the total aeration time in a typical cycle, but not likely affected by the time
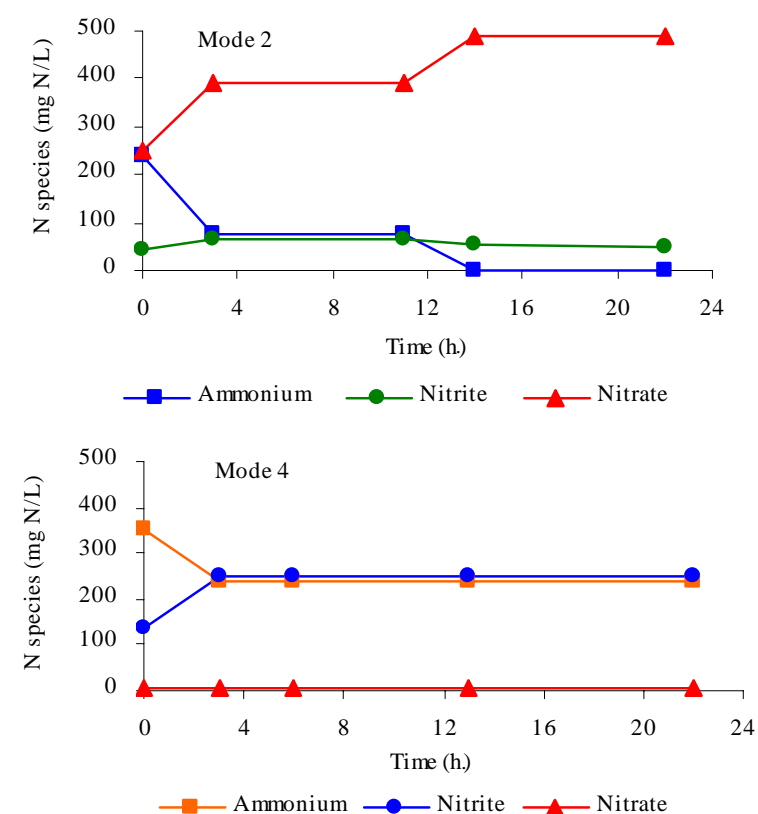

Fig. 7: Typical cycle nitrogen species concentration determination in four operation modes 
distributions of aerations. Therefore, the SBR partial nitrification can be divided into a few successive aerobic/anoxic phases, allowing a concurrent denitrification in the anoxic phase to avoid high nitrite accumulation imparting toxicity to the denitrification microorganisms. Indeed, the successive nitritation (aerobic) and denitrification (anoxic) was currently performed to treat the anaerobically-rejected wastewater containing around $1000 \mathrm{mg} / \mathrm{L}$ of $\mathrm{NH}_{4}^{+}-\mathrm{N}$ in the laboratory-scale SBR process (Fux et al., 2006; Galí et al., 2007). Consistent with the results the partial nitritation along with simultaneous denitrification was successfully obtained when the total aeration time was designed as 3.5 and $4 \mathrm{~h}$. respectively, for one typical cycle divided into three successive aerobic/anoxic subphases (Fux et al., 2006; Galí et al., 2007).

\section{CONCLUSIONS}

The effects of DO concentration and aeration time on nitrification and nitrite accumulation were investigated considering the high initial capital and operating costs of the aeration facilities for wastewater treatment. Both ammonium and nitrite oxidation kinetics were inhibited at low DO concentration of $0.5 \mathrm{mg} \mathrm{O}_{2} / \mathrm{L}$. The extent of nitrite accumulation was facilitated at DO concentration $\sim 1 \mathrm{mg} \mathrm{O}_{2} / \mathrm{L}$, and the rate of ammonium oxidation in this DO level showed a comparable value with that at higher oxygen concentrations. At DO concentration of $\sim 1 \mathrm{mg} \mathrm{O}_{2} / \mathrm{L}$, aeration time significantly affected the nitrification performance. With $3 \mathrm{~h}$. of aeration time, nearly 1:1 nitrite/ammonium ratio was yielded that could make the wastewater suitable for treatment by Anammox process. In accordance to the experimental results, based on the nitrogen strength of wastewater and MLSS concentration in the reactor at DO concentration $\sim 1$ mg $\mathrm{O}_{2} / \mathrm{L}$, aeration time determined by feasibility experiments must be taken into account in the design stage for efficient partial nitrification and subsequent nitrogen removal processes.

\section{ACKNOWLEDGEMENT}

This experimental work was supported by the research grants from the University of Ulsan, Ulsan, South Korea

\section{REFERENCES}

Abeling, U.; Seyfried, C. F., (1992). Anaerobic-aerobic treatment of high strengthammonium wastewater nitrogen removal via nitrite, Water Sci. Tech., 26 (5-6) , 1007-1015.
Ahn, Y. H., (2006). Sustainable nitrogen elimination biotechnologies: A review. Proc. Biochem., 41 (8), 17091721.

Antileo, C.; Werner, A.; Ciudad, G.; Muñoz, C.; Bornhardt, C.; Jeison, D.; Urrutia, H., (2006). Novel operational strategy for partial nitrification to nitrite in a sequencing batch disk reactor. Biochem. Eng. J., 32 (2), 69-78.

APHA, (1998). Standard methods for the examination of water and wastewater, $20^{\text {th }} \mathrm{Ed}$. Washington, DC, USA.

Bae, W.; Baek, S.; Chung, J.; Lee, Y., (2001). Optimal operational factors for nitrite accumulation in batch reactors. Biodegrad., 12 (5), 359-366.

Beccari, M.; Pinto, A. C. D.; Ramadori, R.; Tomei, M. C., (1992). Effects of dissolved oxygen and diffusion resistances on nitrification kinetics. Water Res., 26 (8), 1099-1104.

Bougard, D.; Bernet, N.; Chèneby, D.; Delgenès, J. P., (2006). Nitrification of a high-strength wastewater in an inverse turbulent bed reactor: Effect of temperature on nitrite accumulation. Proc. Biochem., 41 (1), 106-113.

Chuang, H. P.; Ohashi, A.; Imachi, H.; Tandukar, M.; Harada, H., (2007). Effective partial nitrification to nitrite by downflow hanging sponge reactor under limited oxygen condition. Water Res., 41 (2), 295-302.

Ciudad, G.; Rubilar, O.; Muñoz, P.; Ruiz, G.; Chamy, R.; Vergara, C.; Jeison, D., (2005). Partial nitrification of high ammonia concentration wastewater as a part of a shortcut biological nitrogen removal process. Proc. Biochem., 40 (5), 17151719.

Dijkman, H.; Strous, M., (1999). Process for ammonia removal from wastewater. Patent; PCT/NL99/00446.

EPA, (1993). Nitrogen control. Washington (DC): US EPA.

EPA, (1975). Process design manual for nitrogen control. Washington (DC): US EPA.

Fux, C.; Velten, S.; Carozzi, V.; Solley, D.; Keller, J., (2006). Efficient and stable nitritation and denitritation of ammonium-rich sludge dewatering liquor using an SBR with continuous loading. Water Res., 40 (14), 2765-2775.

Fux, C.; Boehler, M.; Huber, P.; Brunner, I.; Siegrist, H., (2002). Biological treatment of ammonium-rich wastewater by partial nitritation and subsequent anaerobic ammonium oxidation (anammox) in a pilot plant. J. Biotech., 99 (3), 295-306.

Galí, A.; Dosta, J.; Van Loosdrecht, M. C. M.; Mata-Alvarez, J., (2006). Biological nitrogen removal via nitrite of rejected water with a SBR and chemostate SHARON/denitrification process. Ind. Eng. Chem. Res., 45 (22), 7656-7660.

Galí, A.; Dosta, J.; Van Loosdrecht, M. C. M.; Mata-Alvarez, J., (2007). Two ways to achieve an anammox influent from real reject water treatment at lab-scale: Partial SBR nitrification and SHARON process. Proc. Biochem., 42 (4), 715-720.

Hanaki, K.; Wantawin, C.; Ohgaki, S., (1990). Nitrification at low levels of dissolved oxygen with and without organic loading in a suspended-growth reactor. Water Res., 24 (3), 297-302.

Hellinga, C.; Van Loosdrecht, M. C. M.; Heijnen, J. J., (1997). The Sharon process for nitrogen removal in ammonium rich waste water. Mededelingen Faculteit Iand bouwwetenschappen, Universiteit Gent 62 (4b). 1743-1750.

Khin, T.; Annachhatre, A. P., (2004). Novel microbial nitrogen removal processes. Biotech. Adv., 22 (7), 519-532. 
Kim, D. J.; Lee, D. I.; Keller, J., (2006). Effect of temperature and free ammonia on nitrification and nitrite accumulation in landfill leachate and analysis of its nitrifying bacterial community by FISH. Biores. Tech., 97 (3), 459-468.

McCarty, P. L.; Beck, L.; St Amant, P., (1969). Biological denitrification of wastewaters by addition of organic materials: Proc 24 ${ }^{\text {th }}$ Industrial Waste Conference, West Lafayette, IN, USA, 1271-1285.

Mosquera-Corral, A.; González, F.; Campos, J. L.; Méndez, R., (2005). Partial nitrification in a SHARON reactor in the presence of salts and organic carbon compound. Process Biochem., 40 (9), 3109-3118.

Mulder, A.; Van de Graaf, A. A.; Robertson, L. A.; Kuenen, J. G., (1995). Anaerobic ammonium oxidation discovered in a denitrifying fluidized bed reactor. FEMS Microbiol. Ecol., 16 (3), 177-184

Ruiz, G.; Jeison, D.; Rubilar, O.; Ciudad, G.; Chamy, R., (2006). Nitrification-denitrification via nitrite accumulation for nitrogen removal from wastewaters. Biores. Tech., 97 (2), 330-335.

Ruiz, G.; Jeison, D.; Chamy, R., (2003). Nitrification with high nitrite accumulation for the treatment of wastewater with high ammonia concentration. Water Res., 37 (6), 13711377.

Stenstrom, M. K.; Poduska, R. A., (1980). The effect of dissolved oxygen concentration on nitrification. Water Res., 14 (6), 643-649.

Tchobanoglous, G.; Burton, F. L.; Stensel, H. D., (2002). Wastewater Engineering: Treatment and Reuse, Fourth Edition, Metcalf and Eddy, Inc: New York.

Teichgraber, B.; Stein, A., (1994). Nitrogen elimination from sludge treatment reject water comparison of the steamstripping and denitrification processes. Water Sci. Technol., 30 (6), 41-51.

Tseng, C. C.; Potter, T. G.; Koopman, B., (1998). Effect of influent chemical oxygen demand to nitrogen ratio on a partial nitrification/complete denitrification process. Water Res., 32 (1), 165-173.

Verstraete, W.; Philips, S., (1998). Nitrification-denitrification processes and technologies in new contexts. Environ. Pollut., 102 (1), 717-726.

Wang, J.; Yang, N., (2004). Partial nitrification under limited dissolved oxygen conditions. Proc. Biochem., 39 (10), 1223-1229.

\section{AUTHOR (S) BIOSKETCHES}

Guo, X., Ph. D., Post doctoral researcher at the Department of Civil and Environmental Engineering, University of Ulsan, South Korea. Email: guoxjjack@yahoo.com

Kim, J. H., Ph.D., Researcher at the Ulsan Eco Center, Korea Industrial Complex Corporation, South Korea. Email: kingtoe@ulsan.ac.kr

Behera, S. K., Ph.D. scholar at the Department of Civil and Environmental Engineering, University of Ulsan, South Korea. Email: shishir_kb@yahoo.com

Park, H. S., Ph.D. Full Professor at the Department of Civil and Environmental Engineering and Director of the Ecosystems Laboratory, University of Ulsan, South Korea. Email: parkhs@ulsan.ac.kr

\section{This article should be referenced as follows:}

Guo, X.; Kim, J. H.; Behera, S. K.; Park, H. S., (2008). Influence of dissolved oxygen concentration and aeration time on nitrite accumulation in partial nitrification process. Int. J. Environ. Sci. Tech., 5 (4), 527-534. 